therapy which now have particular importance. Thus, a good deal of space is given to gentamycin, a family of antibiotics produced by species of Micromonospora, which appears to be related chemically to neomycin and kana. mycin. This product aroused interest because it showed high activity against many Gram-negative pathogens, including Pseudomonas aeruginosa, which is resistant to most of the antibiotics in common use. But, although it may have a place in the chemotherapy of urinary tract infections, toxicity appears to limit the usefulness of gentamycin for the treatment of bacteriæmias.

A further section contains articles on the use of one of the cephalosporins-cephalothin-and some of the new penicillins for the treatment of a variety of infections, including infections of the urinary tract and bacteriæmias caused by penicillinase-producing staphylococci and by Gram-negative bacilli. These substances are made attractivo by their rapid bactericidal action and low toxicity, and it seems that the cephalosporins show the interesting property of provoking no reaction in patients hypersensitive to the penicillins. Together, they widen considerably the possibilities of safe and effective therapy in bacterial disease. But some organisms, such as species of Pseudomonas, have so far remained outside their scope, and the existence of different $\beta$-lactamases with penicillinase or cephalosporinase activity, or both, still imposes limitations on their range of usefulness.

Despite the revolution in bacterial chemotherapy brought about by antibiotics, the continued importance of measures designed to diminish the incidence of infection in hospitals can scarcely be over-emphasized. The authors of one paper estimate that 31,000 deaths from bacteriæmia by Gram-negative rods might have been prevented in American hospitals in 1962 if safer methods of catheterization had been used. Other papers deal with cross-infection and infection after surgery.

In addition to many articles concerned with the use of antibiotics there are several papers on the chemistry of antibiotics, including two on unusual peptides, one paper on the role of acetate in biosynthesis and others which deal with the mode of action of penicillin, streptomycin, erythromycin and polyene antibiotics respectively. One of the latter, by J.' $T$. Park, leads to the interesting conclusion that penicillin inhibits enzymes concerned with mucopeptide synthesis only under conditions of cell growth and that this is the real reason why penicillin only kills growing cells.

This book contains a number of articles of high quality and its range of topics is likely to make it of wider interest than some of its predecessors.

E. P. Abraham
The volume also contains a message from H.R.H. the Duke of Edinburgh, an address by the president of the Congress, D. P. Cuthbertson, special plenary lectures on "Nutrition and Numbers" and "Nutritional Factors in Gallstone Formation" by J. G. Harrar and H. Dam, respectively, and abstracts of some 450 papers road at sessional meetings. About 1,300 names are given in a list of mombers; the Congress was thus not exceptionally large as international scientific congresses go nowadays.

In the wide field of subjects covered, there was some emphasis on nutrition in the developing countries, though the majority of members came from the United Kingdom and the United States, with continental Europoan countries less fully represented. The small number of members from Asia, Africa and Latin America made useful contributions. An optimistic note was struck in many of the papers dealing with protein-calorie deficiency disease, reflecting the progress made in investigating and attacking this world-wide problem during recent years. There was, however, recognition of the vital importance of the 'population explosion' and its effects on world food requirements. Advances in biochemical and physiological research related to nutrition were the theme of some of the symposia, for example, those concerned with growth, trace eloments, absorption, endocrines and the use of isotopes in nutritional investigations. The symposium on diet and cardiovascular disease produced nothing very now. At the special plenary session on "Nutrition as the Servant of Man", held at the end of the Congress, papers were delivered on "Food as a Function of History", "Nutritional Problems of Tanganyika", "Nutrition and World Health", "Application of Nutritional Research to Practical Problems of Nutrition", "The Challenge of the Pre-school Child", and "The Pre-school Protection Programme". These titles illustrate some of the broad issues which particularly interest workers in nutrition and associated fields to-day.

The volume is excollently printed and the editors are to be congratulated on having prepared it for publication in so short a space of time. It does not deal with the social side of the Congress, which was well organized; it can be taken for granted that participants in any scientific congress held in Edinburgh will enjoy themselves. The purpose of this Congress as a whole was well stated in the Duke of Edinburgh's message: "Knowledge in the field of nutrition has grown onormously during the past few years, and it has become more than ever imperative for those engaged in providing and applying this new knowledge to come together periodically and to survey the position".

W. R. AYKROYD

\section{PROBLEMS OF NUTRITION}

\section{Proceedings of the Sixth International Congress of Nutrition}

Edinburgh, 9th to 15th August 1963. General Editors: C. F. Mills and R. Passmore. Pp. $x v+683$. (Edinburgh and London: E. and S. Livingstone, Ltd., 1964.) 105s. net.

THE sixth International Congress of Nutrition, held in Edinburgh during August 9-15, 1963, centred on a series of symposia on the following subjects: nutrition and health; nutrition and early growth; dietary factors in the genesis of cardiovascular disease in man; nutrition in developing populations; animal production under adverse climatic conditions; nutritional and functional aspects of trace element metabolism; protein-calorie deficioney and its amelioration; absorption of nutrients; endocrine function and reproduction in relation to nutrition; balance experiments and isotopes in nutritional investigations. The papers delivered at these symposia, and also those delivered at a special plenary session on "Nutrition as the Servant of Man", are reproduced in full in the Proceedings.

\section{LAMARCK AS A GEOLOGIST}

\section{Hydrogeology}

By J. B. Lamarck. Translated by Prof. Albert V. Carozzi. Pp. vi + 152. (Urbana, Ill.: University of Illinois Press, 1964.) 4.75 dollars.

TEAN Baptiste Lamarck (1744-1829), tho founder of $\mathcal{J}$ invertebrate palæontology and the begetter of a theory of evolution, indirectly contributed much to the advancement of the science of geology. His systematic study of fossil shells in the Paris Basin helped to establish the science of palæontological stratigraphy, while his theory of evolution passing through the hands of Lyell and Charles Darwin provided geology with a method and a doctrine. In contrast to these important contributions to science, we have the work, Hydrogéologie, which was published in 1802 at his own expense. The book is something of a curiosity, b эcause, while it raises new and most fundamental problems in geology, at the same time it produces what would be considered nowadays the most fantastic solutions. Lamarck's contemporaries derided it, later generations forgot it, and historians of geology, with the 